\title{
The Use of Cassava Starch in Earth Burnt Bricks
}

\author{
Olekwu Benjamin Elah\# $\#^{1}$ and Aliyu D. Ibn Sa'id\# \\ ${ }^{*}$ Department of Building, Federal University of Technology, Minna, Nigeria
}

\begin{abstract}
This paper focused on the use of cassava starch as an additive in burnt earth bricks. Burnt earth bricks is one of the oldest building materials in use and abundantly found everywhere with affordable and reasonable cost. With regard to the availability of cassava in most part of the country, looking into the possibility of using cassava starch as an additive for burnt earth bricks production is of great importance in other to enhance their physical property, such as water absorption, abrasion resistance and compressive strength. Cassava starch content of $0 \%, 4 \%, 6 \%, 10 \%$ and $12 \%$ were used in the mix. Batching mix by volume was adopted to get the quantity of material to be use. The specimens were produced in $100 \mathrm{~mm}$ cube mould, demoulded after 24 hours and air dry for 28 days of curing before burning in an electric furnace at a temperature of $1000^{\circ} \mathrm{C}$ for a period of two hours. The result gotten from the research show that water absorption of burnt earth bricks was drastically reduced with the incorporation of cassava starch in the mix. Abrasion resistance and compressive strength of the earth burnt bricks were increased from $4.09 \mathrm{~cm} 2 / \mathrm{g}$ to $27 \mathrm{~cm} 2 / \mathrm{g}$ and from $1.19 \mathrm{~N} / \mathrm{mm}^{2}$ to $2.19 \mathrm{~N} / \mathrm{mm}^{2}$ respectively at cassava starch content of $6 \%$. Satisfactory performance of the earth burnt bricks was achieved at an optimum amount of $6 \%$ of cassava starch content and is thus recommended for incorporation as an additive in producing earth burnt bricks.
\end{abstract}

Keywords — Earth Burnt Bricks, Cassava Starch, Use.

\section{INTRODUCTION}

The brick is one of the oldest building materials in used today. It could be made from ordinary soil (earth) or clay. Soil is one of the primary materials used for construction of traditional low-cost housing in Nigeria and is well suited to local weather conditions and occupancy patterns. Buildings are constructed entirely, or partially of soil, depending on location, climate, available skills, cost, building use and local tradition (Adam and Agib [1].

In terms of material, bricks are classified into soil bricks and clay bricks and by method of construction, each class can be further classified into fired (burnt) and unfired (unburnt) bricks. Burnt bricks, whether Earth (soil) or clay bricks, are stronger and more durable than unburnt bricks. Burnt clay bricks are stronger and more durable but more costly to produce than burnt earth bricks. But the incorporation of chemical additives in ordinary earth burnt bricks can enhance their properties. It is on this premise that this research is using cassava starch as an additive in earth burnt bricks with the aim of improving their properties so as to be comparable to burnt clay bricks. The objective of this work is to improve the properties of earth burnt bricks such as moisture absorption, abrasion resistance and compressive strength by using cassava starch (from cassava liquid waste in local 'gari' and 'fufu' (akpu) processing industries) as an additive during the production process. In so doing, the cassava liquid waste which contributes to environmental pollution could be utilized thereby relieving the environment of such pollution.

\section{OVER VIEW AND REFERENCE TO RELATED WORKS}

The Encarta English Dictionary [2] define brick as a rectangular block of clay or similar material (i.e. laterite) that is baked until is hard and is used for building houses, walls or other permanent structures. According to Olawuyi, Olusola, Ogunbode and Kyenge [3], "usage of burnt bricks dates back to the stone age (i.e. $2500 \mathrm{BC}$ ) as recorded in the Bible story of 'The Tower of Babel' in Genesis chapter 11 verse 3 where the people were said to make bricks and burn them thoroughly."

Bricks can be produced from a variety of soils ranging from ordinary loamy soil, clay or laterite. According to Olawuyi et $a l$. [3] the soil used for brick making is often called different names such as earth, clay or laterite.

Properties of bricks can be enhanced by either burning at high temperature of incorporating additives such as cement and other pozzolanic materials or chemical additives.

Olawuyi et al [3]. conducted a research into two samples of Makurdi Burnt Bricks and found that the compressive strengths were $3.46 \mathrm{~N} / \mathrm{mm}^{2}$ and $11.75 \mathrm{~N} / \mathrm{mm}^{2}$ for samples A and $\mathrm{B}$ respectively while the average water absorption for sample B $(16.49 \%)$ was double that of sample A $(8.58 \%)$ and the abrasion resistance ability of sample B (33.67\%) was four times better than sample A $(9.32 \%)$.

Jahagirdar, Shrihari and Manu [4] carried out investigation into the utilization of textile mill sludge in burnt clay bricks and found out that the density of bricks, compressive strength and ringing sound reduces as sludge content in bricks increases whereas water absorption and efflorescence increases. They recommended textile mill sludge up to $15 \%$ to be added so as to get compressive strength greater than 3.5 $\mathrm{N} / \mathrm{mm}^{2}$.

Okeniyi, Adeniji and Dahunsi [5] carried out an investigation on the effects of chemical additives in the production of structural bricks. They used one industrial chemical additive known as KS770 and another local one known as soda ash for producing samples of sun-dried (unfired) and oven burnt (fired) structural bricks in addition to a set of non chemical samples for comparison. According to them, "the results obtained show that KS770 being concrete chemical plasticizer adversely increase clay moisture content, hence can only be used at reduced quantity of water to yield higher compressive strength compared to non chemical one. Samples with soda 


\section{International Journal of Engineering Trends and Technology (IJETT) - Volume17 Number 8-Nov2014}

ash prove to be a good plasticizer and water reducing agent with highest strength at lowest density."

In this research, cassava starch (gotten from cassava liquid waste in local gari processing industries) is used as an additive in the production of earth burnt bricks to enhance their properties. Cassava, the raw material and its process to produce starch is relatively cheap. There is availability of cassava in many parts of Nigeria such as Bunue, Nasarawa, Cross River, Akwa Ibom, Delta, Ogun, Ondo, Enugu, Abia, Imo and Kaduna. The utilization of such waste product will reduce environmental pollution and be a source of income to the local gari processing industries.

\section{MATERIALS AND EXPERIMENTAL PROCEDURES}

The materials used in this investigation are powdered fruit pods of acacia tree (PFPAT) as a local rendering admixture; fine reddish-brown (FRB) soil and fine light-brown (FLB) soil.

\section{A. Materials Used}

The Materials used in this work include, earth (loamy soil), starch and water. The loamy soil was obtained near the gate to Federal University of Technology Main Campus at Gidan Kwano in Minna, Niger State, Nigeria. Preliminary tests on the soil shows it has a moisture content of $8.51 \%$, specific gravity of 2.3 , liquid limit of $26 \%$, plastic limit of $19.20 \%$ and plasticity index of $6.80 \%$.

The cassava starch powder was produced from cassava liquid waste gotten from local gari processing industry. The starch was prepared by mixing $200 \mathrm{~g}$ of cassava starch powder with cold water to form slurry and then $800 \mathrm{~g}$ of boiling water was added to the slurry to produce the required paste of standard consistence.

The water used was portable tap water.

\section{B. Experimental Procedures}

Varying amount of cassava starch in the range of $0 \%, 4 \%, 6 \%$, $8 \%, 10 \%$ and $12 \%$ by weight of earth were added to the mixture to produce the bricks in $100 \mathrm{~mm}$ cube mould. The procedure described in BS 1377: part 4: 1990 (clause 3.3.4.1) was used [6]. A total number of thirty cubes of burnt bricks were produced. They were air dried for twenty eight days before burning them in a furnace at a temperature of $1000^{\circ} \mathrm{C}$ for 2 hours.

\section{Water Absorption Test}

Water absorption test is normally carried out to determine the suitability of a brick for construction works. According to Rajput [7] cited in Olawuyi et al. [3] the water absorption of a good brick should not exceed $20 \%$ weight of the dry brick.

In the water absorption test, the burnt bricks were first weighed (say $\mathrm{W}_{1}$ ) and then immersed in a drum of water making sure that the water cover it to the top and left for 24 hours. After 24 hours, the specimens are weighed again (say $\left.\mathrm{W}_{2}\right)$. Water absorption is calculated as $\left(\mathrm{W}_{1}-\mathrm{W}_{2}\right) \times 100 / \mathrm{W}_{1}$.

\section{Abrasion Resistance Test}

Abrasion resistance test is a measure of durability which determines the ability of the brick to resist wearing away by erosion and other environmental conditions. The test was carried out in accordance with the procedure described in BS 1881 - 122:1983 [8]. In this test, the brick sample was weighed before inserting in the machine and then subjected to 500 revolutions and weighed again. The abrasion resistance was calculated in terms of $\%$ durability as $\mathrm{D}=100-\{(\mathrm{W} 1-$ W2)x100/W1\}The difference in weight calculated in percentage $(\%)$ gives an indication of the $\%$ durability of the brick sample while the average of three replicate was adopted in this study as the \% durability.

\section{Compressive Strength}

The compressive strength test was carried out in accordance with the procedures described in BS 1881 [9] using Digital Display Building Material Compression Testing Machine Model JYS-2000A Class 1.

\section{RESULTS AND DISCUSSION}

\section{A. Water Absorption}

The result of the water absorption test is presented in Table 1 and Figure 1 shows the variation of water absorption with cassava starch content.

\begin{tabular}{lllll}
\multicolumn{5}{c}{ Table 1 Water Absorption Test of the Burnt Earth Bricks Results } \\
\hline $\begin{array}{l}\text { \% of } \\
\text { cassava }\end{array}$ & Mass after & $\begin{array}{l}\text { Mass after } \\
\text { buming(g) }\end{array}$ & $\begin{array}{l}\text { Change in } \\
\text { mass }(\mathrm{g})\end{array}$ & $\begin{array}{l}\% \text { weight } \\
\text { gain }\end{array}$ \\
starch & & & & \\
\hline 0 & 1548 & 1835 & 287 & 19 \\
4 & 1630 & 1789 & 159 & 9.8 \\
6 & 1630 & 1769 & 139 & 8.5 \\
10 & 1633 & 1760 & 127 & 7.8 \\
12 & 1640 & 1770 & 130 & 7.9 \\
\hline
\end{tabular}

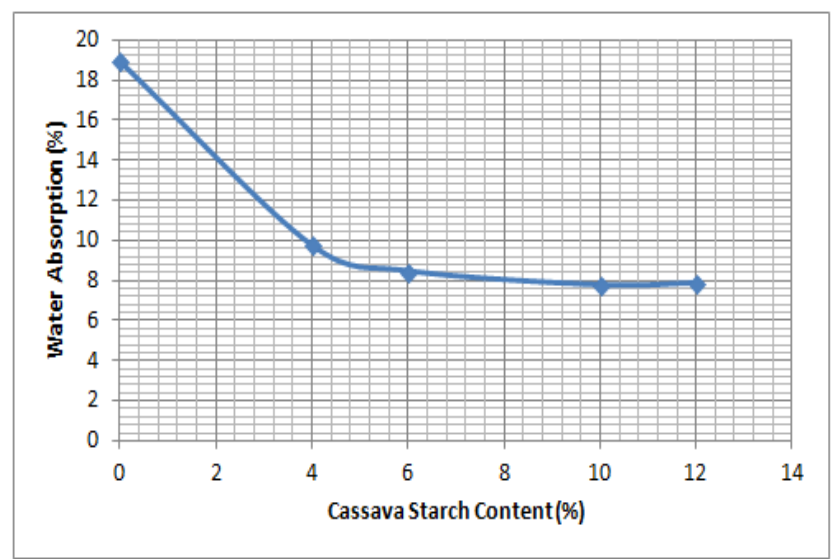

Figure 1: Variation of Moisture Absorption of Burnt Earth Bricks with Cassava Starch Content

It can be observed from Figure 1 that as cassava starch content increases, water absorption increases up to $6 \%$ cassava starch content and then remains almost constant with further increase in cassava starch content. The use of cassava 
International Journal of Engineering Trends and Technology (IJETT) - Volume17 Number 8-Nov2014

starch reduced water absorption of the burnt bricks from $19 \%$ to $8.5 \%$ at cassava starch content of $6 \%$.

\section{B. Abrasion Resistance}

The result of the abrasion test is as presented in Table 2 and variation of abrasion resistance with cassava starch content is illustrated in Figure 2.

\begin{tabular}{|c|c|c|c|c|}
\hline $\begin{array}{l}\text { Cassava } \\
\text { Starch } \\
(\%)\end{array}$ & $\begin{array}{l}\text { Mass before } \\
\text { buming(g) }\end{array}$ & $\begin{array}{l}\text { Mass after } \\
\text { buming(g) }\end{array}$ & $\begin{array}{l}\text { Mass after } \\
\text { brushing(g) }\end{array}$ & $\begin{array}{l}\text { Abrasion } \\
\text { Resistance } \\
\left(\mathrm{cm}^{2} / \mathrm{g}\right)\end{array}$ \\
\hline 0 & 1695 & 1548 & 1515 & 4.09 \\
\hline 4 & 1698 & 1630 & 1605 & 5.40 \\
\hline 6 & 1699 & 1630 & 1625 & 27.00 \\
\hline 10 & 1739 & 1633 & 1620 & 10.38 \\
\hline 12 & 1762 & 1640 & 1630 & 13.5 \\
\hline
\end{tabular}

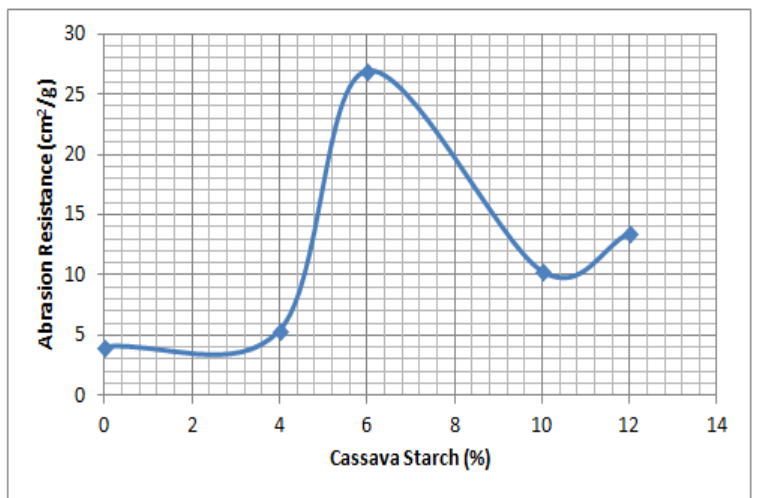

Figure 2 Variation of Abrasion Resistance With Cassava Starch Content

From Figure 1, it can be observed that as cassava starch content increases, abrasion resistance increases up to $6 \%$ cassava starch content and then begins to reduce as cassava starch content increases further. This trend is an indication the $6 \%$ cassava starch is the optimum amount for maximum abrasion resistance. The use of cassava starch increased abrasion resistance of the burnt bricks from $4.09 \mathrm{~cm}^{2} / \mathrm{g}$ to $27 \mathrm{~cm}^{2} / \mathrm{g}$ at cassava starch content of $6 \%$.

\section{Compressive Strength}

The compressive strength results are presented in Table 3 and the variation of compressive strength with cassava starch content is illustrated in figure 3 .
Table 3 Compressive Strength of Burnt Earth Bricks Results

\begin{tabular}{|c|c|c|c|c|c|}
\hline $\begin{array}{l}\text { \%of } \\
\text { cassava } \\
\text { starch }\end{array}$ & $\begin{array}{l}\text { Mass } \\
\text { before } \\
\text { burning(g) }\end{array}$ & $\begin{array}{l}\text { Mass after } \\
\text { burning(g) }\end{array}$ & Area $\left(\mathrm{mm}^{2}\right)$ & $\begin{array}{l}\text { Ultimate } \\
\text { load(kg) }\end{array}$ & $\begin{array}{l}\text { Compressive } \\
\text { Strength } \\
\mathrm{N} / \mathrm{mm}^{2}\end{array}$ \\
\hline 0 & 1695 & 1548 & $(100 \times 100)$ & 11.9 & 1.19 \\
\hline 4 & 1698 & 1630 & $(100 \times 100)$ & 15.5 & 1.55 \\
\hline 6 & 1699 & 1630 & $(100 \times 100)$ & 21.9 & 2.19 \\
\hline 10 & 1739 & 1633 & $(100 \times 100)$ & 14.5 & 1.46 \\
\hline 12 & 1762 & 1640 & $(100 \times 100)$ & 13.1 & 1.31 \\
\hline
\end{tabular}

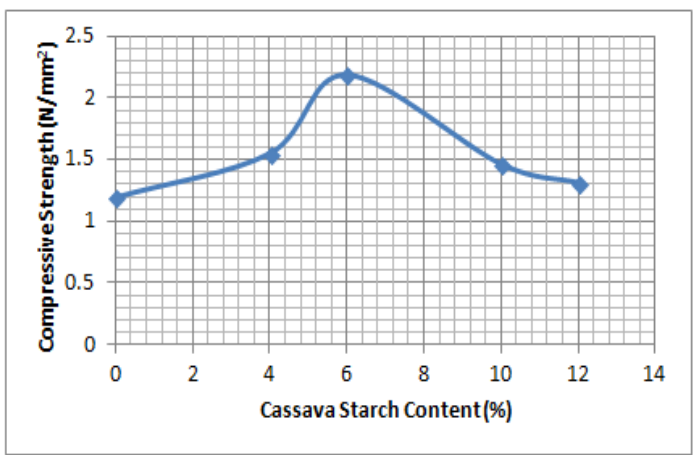

Figure 3 Variation of Compressive Strength of Burnt Earth Bricks with Cassava Starch Content

In similar manner like for abrasion resistance, as cassava starch content increases, compressive strength increases up to 6\% cassava starch content and then begins to reduce as cassava starch content increases further. This trend again is an indication that $6 \%$ cassava starch is the optimum amount of cassava starch for maximum strength performance which corresponds to $2.19 \mathrm{~N} / \mathrm{mm}^{2}$.

\section{CONCLUSION AND RECOMMENDATION}

The use of cassava starch (gotten from cassava liquid waste from local gari and fufu processing industries) in earth burnt bricks has been found to reduce water absorption and increase both abrasion resistance and compressive strength of the bricks.

Water absorption of burnt earth bricks was drastically reduced with the incorporation of cassava starch in the mix. Abrasion resistance and compressive strength of the earth burnt bricks were increased from $4.09 \mathrm{~cm} 2 / \mathrm{g}$ to $27 \mathrm{~cm} 2 / \mathrm{g}$ and from $1.19 \mathrm{~N} / \mathrm{mm}^{2}$ to $2.19 \mathrm{~N} / \mathrm{mm}^{2}$ respectively at cassava starch content of $6 \%$. Satisfactory performance of the earth burnt bricks was achieved at an optimum amount of $6 \%$ of cassava starch content and is thus recommended for incorporation as an additive in producing earth burnt bricks.

\section{REFERENCES}

[1] E.A. Adam and A.R.A. Agib, (2001), Compressed Stabilized earth British Standard Institution (1990), British Standard methods of test for soils for civil engineering purposes, BS 1377: Part 4, Compactionrelated tests, British Standards Institution, London. 
International Journal of Engineering Trends and Technology (IJETT) - Volume17 Number 8-Nov2014

[2] Encarta English Dictionary (2009); Website: www.microsoft_encarta.microsoft

[3] Olawuyi, B. J.; Olusola, K. O. Ogunbode, E. B. and Kyenge S. S. (2013), Performance Assessment of Makurdi Burnt Bricks. Available online at http://followscience.com/content/526429/performanceassessment-of-makurdi-burnt-bricks. Accessed on $15^{\text {th }}$ October, 2014.

[4] Shrikant S Jahagirdar, S. Shrihari, B Manu (2013), Utilization of Textile Mill Sludge in Burnt Clay Bricks, International Journal of Environmental Protection May. 2013, Vol. 3 Iss. 5, PP. 6-13.

[5] Okeniyi, A. G., Adeniji, S. O. and Dahunsi B. I. O (2012) Effects of Chemical Additives on the Production of Structural Brick for Construction Works, Journal of Chemical, Mechanical and Engineering Practice, Vol. 2 No. 3, pp. 18-23.

[6] British Standards Institution (1990), British Standard methods of test for soils for civil engineering purposes: BS1377: Part 4, Compactionrelated tests. London.

[7] Rajput, R. K. (2006); Engineering Materials, S. Chand \& Company Limited, New Delhi, India.

[8] British Standard Institution (1983); Testing Concrete - Method of Determination of Water Absorption, BS 1881: Part 122, British Standard Institution, London.

[9] British Standard Institution, (1970), Methods of testing concrete for strength, BS 1881: Part 4: British Standard Institution, London. 